\title{
Functional Tremor: Palatal Tremor Fonksiyonel Tremor: Palatal Tremor
}

\author{
(1) Dilara Mermi Dibek, (1) Onur Bulut, (1) Berril Dönmez Çolakoğlu, (1) Raif Çakmur \\ Dokuz Eylul University Faculty of Medicine, Department of Neurology, Division of Clinical Neurophysiology, Izmir, Turkey
}

\begin{abstract}
Palatal tremor is a rare type of tremor. Although there are structural lesions and neurodegeneration in its etiology, it can also be seen functionally. Its diagnosis is made by oropharynx inspection in neurological examination, and prognosis and treatment management are directed by etiologic classification. We aimed to discuss functional palatal tremor in a 29-old male patient.
\end{abstract}

Keywords: Functional, palatal, tremor

\section{Öz}

Palatal tremor nadir görülen bir tremor türüdür. Etiyolojisinde yapısal lezyonlar ve nörodejenerasyon olmakla birlikte fonksiyonel olarak da karşımıza çıabilmektedir. Nörolojik muayenede orofarinks inspeksiyonu ile tanı konulmakta, etiyolojik sınıflama yapılarak prognoz tayini yapılmakta ve tedavi yönetimine yön verilmektedir. Kliniğimizde takip edilen 29 yaşındaki bir erkek hastanın bildirimi ile fonksiyonel palatal tremoru tartışmayı amaçlamaktayız.

Anahtar Kelimeler: Fonksiyonel, palatal, tremor

\section{Introduction}

Tremor is an involuntary, rhythmic and oscillatory movement disorder. It is the most common movement disorder. Its frequency and rhythm, involved body area and condition due to activation (resting or activation) are considered in its classification and naming (1).

Palatal tremor is a rhythmic tremor of the soft palate with $0.5-3$ $\mathrm{Hz}$ frequency. It is accompanied by a simultaneous click in the ear (2).

With the presented case, it was aimed to emphasize the points that should be considered in the differential diagnosis of palatal tremor.

\section{Case Report}

A 29-year-old, right-handed male patient was admitted to our outpatient clinic with symptoms of tremor in the palate lasting approximately two and a half years. He stated that he had a tremor in the palate and a clicking sound in his ear and that he did not pay attention to its relationship with sleeping. The patient, who was a secondary school graduate, worked in construction. He had a history of epilepsy, and had been followed up for 15 years without medication and seizures. He had no family history, no consanguinity between his mother and father, no similar findings in the family, and no history of psychiatric illness. The patient, who reported not using medication at admission, stated that he was treated with clonazepam at a dose of $2 \mathrm{mg} /$ day. Although a partial response was achieved, botulinum toxin treatment was administered upon the continuing symptoms and the patient reported that his symptoms improved.

On neurologic examination, it was observed that the palatal tremor was at variable frequencies and the rhythm changed when the patient was instructed for other examinations. When the patient was asked to open and close his hands by extending the arms, it was recorded that arrhythmia became apparent due to the patient's distraction and palatal tremor accompanied the same rhythm synchronously (entrainment), and that the patient could stop the tremor upon request (Video 1, 2, 3, 4). Other systemic and neurologic examinations of the patient were normal. In the laboratory examination, complete blood count, biochemistry, thyroid function tests, serum copper and ceruloplasmin levels, and peripheral smear examination were normal. Cranial magnetic resonance imaging was

Address for Correspondence/Yazışma Adresi: Dilara Mermi Dibek MD, Dokuz Eylul University Faculty of Medicine, Department of Neurology, Division of Clinical Neurophysiology, Izmir, Turkey

Phone: +90 2324125059 E-posta: dilara_mermi@ hotmail.com ORCID: orcid.org/0000-0001-9963-9450

Received/Geliş Tarihi: 03.08 .2019 Accepted/Kabul Tarihi: 09.09.2020

${ }^{\circ}$ Copyright 2020 by Turkish Neurological Society

Turkish Journal of Neurology published by Galenos Publishing House. 
found to be normal. The patient, who stated that there was a partial response to duloxetine, levetiracetam, pyrimidone, valproic acid, flunarizine, and botulinum toxin treatment used for tremor, did not respond to a total of 20 units of onabotulinumtoxin-A treatment administered to bilateral tensor veli palatini muscles.

The defined palatal tremor was considered functional palatal tremor because of the variable frequency and incremental course detected in the examination, its synchronization with another synchronous movement, and the patient's ability to stop it voluntarily.

\section{Discussion}

Palatal tremor is examined in two subgroups as essential and symptomatic. There is no lesion or neurodegeneration in essential palatal tremor, and there is more activity in the tensor veli palatini muscle innervated by the trigeminal nerve. In the pathogenesis of symptomatic palatal tremor, lesions located in the GuillianMollaret triangle (dentate nucleus, inferior oliva, nucleus ruber) or neurodegenerative diseases such as neuroferritinopathy, progressive ataxia, and palatal tremor are involved, and the levator muscle innervated by the vagal nerve is affected $(3,4)$.

The diagnosis of palatal tremor is made through neurologic examinations. Involuntary, rhythmic, and same-direction movement of the soft palate is observed on the examination of the oropharynx. In a movement disorder with a psychogenic component, there is variability in the frequency and amplitude with distraction, entrainment, and coactivation. In addition, an increase in movement is observed with an increase in the patient's attention, and it is unresponsive to treatment (5). Arrhythmia during the examination, variability in frequency, amplitude or axis or even deceleration of movement with distraction are observed in psychogenic palatal tremor, and when a simultaneous rhythmic movement is performed (e.g. finger tapping or hand opening and closing), the pathologic movement also acquires the same rhythm and can be stopped willingly in psychogenic palatal tremor. Patients with psychogenic palatal tremor usually have pre-existing respiratory infections or other otolaryngeal problems $(6,7)$. In the anamnesis of our patient, there were no such features, but the features in the examination were compatible with psychogenic palatal tremor.

In the treatment of palatal tremor, botulinum toxin treatment is given along with electromyography $(8,9)$. Clonazepam and tetrabenazine can be used as medical treatments (10). Case reports of patients in whom sumatriptan and flunarizine were used are available in the literature $(11,12)$. Although psychogenic movement disorders are resistant to known treatment options, they can benefit from behavioral therapy and psychotropic medication use due to the underlying psychogenic component. Although it was reported in the literature that a response to long-term botulinum toxin could be obtained in the treatment of psychogenic palatal tremors (7), a patient was reported in whom exercise with a mirror stopped the movement disorder successfully (2). In our patient, no benefit was observed with medical treatment, botulinum toxin injection, and the mirror exercise.

Palatal tremor is an uncommon movement disorder. In classification, besides the essential and symptomatic groups, a psychogenic group should be kept in mind and observations should be made accordingly during the examination. It is a disease for which the treatment approach can change, which can sometimes be cured by behavior change. Sometimes, it is difficult to obtain a treatment response.
Ethics

Informed Consent: Patient consent was obtained.

Peer-review: Internally peer-reviewed.

\section{Authorship Contributions}

Surgical and Medical Practices: R.Ç., O.B., D.M.D., Concept: R.Ç., D.M.D., Design: R.Ç., D.M.D., Data Collection or Processing: R.Ç., B.D.Ç., D.M.D., O.B., Analysis or Interpretation: R.Ç., B.D.Ç., Literature Search: D.M.D., R.Ç., Writing: R.Ç., D.M.D.

Conflict of Interest: No conflict of interest was declared by the authors.

Financial Disclosure: The authors declared that this study received no financial support.

Video 1 doi: 10.4274/tnd.2020.48642Video1 Video 1. Palatal tremor at rest

Video 2 doi: 10.4274/tnd.2020.48642Video2 Video 2. Palatal tremor: while the patient is making noise

Video 3 doi: 10.4274/tnd.2020.48642Video 3 Video 3. Palatal tremor: when the patient is asked to stop it

Video 4 doi: 10.4274/tnd.2020.48642Video4 Video 4. Palatal tremor: during distraction and simultaneous contraction

\section{References}

1. Bhatia KP, Bain P, Bajaj N, et al. Consensus Statement on the classification of tremors. from the task force on tremor of the International Parkinson and Movement Disorder Society. Mov Disord 2018;33:75.

2. Kern DS, Lang AE. Successful treatment of functional palatal tremor: Insights into pathogenesis and management. Mov Disord 2015;30:875-876.

3. Wills AJ, Sawle GV, Guilbert PR, Curtis AR. Palatal tremor and cognitive decline in neuroferritinopathy. J Neurol Neurosurg Psychiatry 2002;73:91-92.

4. Samuel M, Torun N, Tuite PJ, Sharpe JA, Lang AE. Progressive ataxia and palatal tremor (PAPT): clinical and MRI assessment with review of palatal tremors. Brain 2004;127(Pt 6):1252-1268.

5. Thomas M, Jankovic J. Psychogenic movement disorders: diagnosis and management. CNS Drugs 2004;18:437-452.

6. Zadikoff C, Lang AE, Klein C. The 'essentials' of essential palatal tremor: a reappraisal of the nosology. Brain 2006;129(Pt 4):832-840.

7. Stamelou M, Saifee TA, Edwards MJ, Bhatia KP. Psychogenic palatal tremor may be underrecognized: reappraisal of a large series of cases. Mov Disord 2012;27:1164-1168.

8. Penney SE, Bruce IA, Saeed SR. Botulinum toxin is effective and safe for palatal tremor: a report of five cases and a review of the literature. J Neurol 2006;253:857-860.

9. Krause E, Heinen F, Gürkov R. Difference in outcome of botulinum toxin treatment of essential palatal tremor in children and adults. Am J Otolaryngol 2010;31:91-95.

10. Jankovic J, Pardo R. Segmental myoclonus. Clinical and pharmacologic study. Arch Neurol 1986;43:1025-1031.

11. Scott BL, Evans RW, Jankovic J. Treatment of palatal myoclonus with sumatriptan. Mov Disord 1996;11:748-751.

12. Cakmur R, Idiman E, Idiman F, Baklan B, Ozkiziltan S. Essential palatal tremor successfully treated with flunarizine. European Neurology, $1997 ; 38: 133-134$. 